\title{
Fruits
}

http://www.fruits-journal.org

Additional services for Fruits:

Email alerts: $\underline{\text { Click here }}$

Subscriptions: Click here

Commercial reprints: Click here

Terms of use : $\underline{\text { Click here }}$

\section{Seasonality and range of fruit fly (Diptera: Tephritidae) host plants in orchards in Niayes and the Thiès Plateau (Senegal)}

Ousmane Ndiaye, Jean-François Vayssieres, Jean Yves Rey, Saliou Ndiaye, Papa Madialéké Diedhiou, Cheikh Tidiane Ba and Paterne Diatta

Fruits / Volume 67 / Issue 05 / September 2012, pp 311 - 331

(C) 2012 Cirad/EDP Sciences

Published online by Cambridge University Press: 04 October 2012

DOI: $10.1051 /$ fruits/2012024

Link to this article: http://www.fruits-journal.org/10.1051/fruits/2012024

How to cite this article:

Ousmane Ndiaye, Jean-François Vayssieres, Jean Yves Rey, Saliou Ndiaye, Papa Madialéké Diedhiou, Cheikh Tidiane Ba and Paterne Diatta (2012). Seasonality and range of fruit fly (Diptera: Tephritidae) host plants in orchards in Niayes and the Thiès Plateau (Senegal). Fruits, 67, pp 311-331 doi:10.1051/fruits/2012024

Request Permissions : $\underline{\text { Click here }}$ 


\title{
Seasonality and range of fruit fly (Diptera: Tephritidae) host plants in orchards in Niayes and the Thiès Plateau (Senegal)
}

\author{
Ousmane NdiAYE ${ }^{1 *}$, Jean-François VAYSSIERES ${ }^{2}$, Jean YVES REY ${ }^{3}$, Saliou NDIAYE ${ }^{1}$, Papa Madialéké DiedHIOU ${ }^{4}$, Cheikh Tidiane BA ${ }^{5}$, \\ Paterne DIATTA ${ }^{1}$
}

\author{
${ }^{1}$ École Natl. Sup. Agric., \\ ENSA, Thiès, Senegal, \\ ousmanen@hotmail.com \\ 2 CIRAD-Persyst, \\ UPR HortSys, IITA, \\ 08 BP 0932, Cotonou, Bénin \\ ${ }^{3}$ CIRAD-Persyst, \\ UPR HortSys, ISRA/CDH, \\ BP 484, Thiès, Senegal \\ ${ }^{4}$ UFR S2ATA, UGB, BP 234, \\ Saint Louis, Senegal \\ 5 Dep. Anim. Biol., FST, UCAD, \\ Dakar, Senegal
}

* Correspondence and reprints

Received 7 December 2011 Accepted 18 January 2012

Fruits, 2012, vol. 67, p. 311-331 (C) 2012 Cirad/EDP Sciences All rights reserved DOI: 10.1051/fruits/2012024 www.fruits-journal.org

RESUMEN EsPañoL, p. 331
Seasonality and range of fruit fly (Diptera: Tephritidae) host plants in orchards in Niayes and the Thiès Plateau (Senegal).

Abstract - Introduction. Senegal produces up to $150,000 \mathrm{t}$ of fruit, of which $60,000 \mathrm{t}$ are mangoes. Fruit production is important for the Niayes region, where $60 \%$ of total production is of mangoes, with citrus production coming next at $24 \%$. Mango losses have become more substantial since the arrival of Bactrocera invadens in Senegal. The pest population increases in the mango ripening period, but little is known about its secondary hosts. Materials and methods. Fruits of cultivated and wild plants were collected regularly from April to December 2008 inside and around 19 orchards in eleven localities in the Niayes and Thiès areas in Senegal. The samples were monitored to identify any fruit flies present so that a list of host plants could be compiled. For mango, the study focused on establishing the influence of certain parameters such as the variety, the fruit size, the color, the flowering pattern and the physiological levels of infestation due to B. invadens and Ceratitis cosyra. Orchards were classified either as traditional (many mango varieties and many fruit species grown together in a stand) or intensive (fields of monovarietal mango trees), according to their composition and how they were managed. Results and discussion. A total of $663.2 \mathrm{~kg}$ of fruit, including those of 24 mango varieties, 13 citrus species with five lime varieties, two orange varieties and four pomelo varieties along with other cultivated and wild plants, were sampled both as fallen fruit and from the trees. Traditional orchards were more infested than the modern ones. B. invadens was significantly dominant over the other flies emerging such as C. cosyra, C. capitata, C. punctata, C. bremii, Bactrocera cucurbitae, Capparimyia bipustulata, Carpomyia sp. and Dacus sp. B. invadens was found on the 24 varieties of Mangifera indica, the 13 citrus species, and the other cultivated plants and wild plants sampled. Some host plants supported a relatively high level of fruit flies before the mango ripening period. Mangifera indica was infested principally by B. invadens and C. cosyra. $C$. cosyra was significantly present on the first fruit trees to flower, mostly in early varieties, while B. invadens infested all the varieties whatever the fruit development stage, the color, or the flowering pattern. Conclusion. Because of the host plants' diversity and varieties the traditional orchards were more infested than the modern ones. The management of this pest needs an Integrated Pest Management system based on a back-to-basics study of the infesting fruit flies, existing parasitoids and their hosts.

Senegal / fruit crops / host plants / Mangifera indica / Citrus / Tephritidae / Bactrocera invadens / Ceratitis cosyra / orchards / sampling

Saisonnalité et gamme des mouches des fruits (Tephritidae, diptères) identifiées dans les plantes hôtes des vergers des Niayes et du plateau de Thiès (Sénégal).

Résumé - Introduction. La production fruitière du Sénégal est estimée à 150.000 t dont 60.000 t de mangues. Les agrumes représentent $24 \%$ de cette production et se situent en seconde position après la mangue qui représente $60 \%$ de la production fruitière très importante dans les Niayes. Depuis l'arrivée de Bactrocera invadens au Sénégal les pertes de production de mangues ont augmenté. Les populations du ravageur sont importantes en période de maturation des fruits mais les informations concernant ses hôtes secondaires sont rares. Matériel et méthodes. Les fruits d'espèces fruitières cultivées et spontanées ont été collectés régulièrement d'avril à décembre 2008, dans et autour de 19 vergers de onze localités de la zone des Niayes et du plateau de Thiès (Sénégal). Ces fruits ont été suivis pour déterminer les espèces de mouches hébergées et répertorier ainsi leurs plantes hôtes. Chez la mangue, l'étude a cherché à montrer l'influence de paramètres tels que la variété, la taille du fruit, la couleur, la vague de floraison ou l'état physiologique sur les infestations par B. invadens et Ceratitis cosyra. En fonction de leur composition et de leur mode de conduite, les vergers ont été classés en deux types : traditionnel (plusieurs variétés de manguiers et plusieurs espèces fruitières cultivées à la fois au sein d'une même parcelle) ou moderne (parcelles monovariétales de manguiers). Résultats et discussion. Au total, $663,2 \mathrm{~kg}$ de fruits issus de 24 variétés de manguiers, 13 espèces d'agrumes, dont 5 variétés de limetier, 2 variétés d'orangers et 4 variétés de pomélos, ainsi que d'autres espèces fruitières cultivées ou spontanées, ont été échantillonnés soit au sol, soit sur l'arbre. Les vergers de type traditionnel ont été plus infestés que les vergers de type moderne. Parmi les Tephritidae issues des fruits collectés, l'espèce $B$. invadens a été significativement dominante sur Ceratitis cosyra, C. capitata, C. punctata, C. bremii, Bactrocera cucurbitae, Capparimyia bipustulata, Carpomyia sp. et Dacus sp. L'espèce B. invadens a été retrouvée chez 24 variétés de Mangifera indica, 19 cultiCarpomyia sp. et Dacus sp. L'espèce B. invadens a été retrouvée chez 24 variétés de Mangifera indica, 19 culti-
vars d'agrumes, et chez d'autres espèces fruitières cultivées et spontanées. Certaines plantes hôtes ont maintenu des niveaux de populations de $B$. invadens avant la période de maturation de la mangue. Le manguier est principalement infesté par $B$. invadens et $C$. cosyra. L'espèce $C$. cosyra est significativement importante dans les fruits issus des premières vagues de floraison et surtout chez les variétés précoces, tandis que B. invadens est présente dans toutes les variétés quels que soient l'état du fruit, sa couleur, la vague de floraison et l'endroit de collecte. Conclusion. Du fait de la diversité des plantes hôtes et des variétés, les vergers traditionnels ont été plus infestés que les vergers modernes. La gestion de ce ravageur nécessite de définir un système de lutte intégrée basée sur une étude de base des mouches des fruits présentes, des parasitoïdes existants et de leurs hôtes.

Sénégal / plante fruitière / plante hôte / Mangifera indica / Citrus / Tephritidae / Bactrocera invadens / Ceratitis cosyra / verger / échantillonnage 


\section{Introduction}

The Niayes zone is one of Senegal's development hot-spots, with commercialized periurban farming and major anthropization [1]. The region is responsible within the national economic plan for a major share of the estimated national fruit production of $150,000 \mathrm{t}^{\mathrm{y}} \mathrm{year}^{-1}$, of which mangoes are about $60 \%$ and citrus fruits $24 \%$. It supplies around $80 \%$ of the mangoes exported Thanks to favorable ecological conditions, yields have reached $10 \mathrm{t} \cdot \mathrm{ha}^{-1}$ in the traditional orchards and $20 \mathrm{t} \cdot \mathrm{ha}^{-1}$ in the modern orchards [2]. Productivity and value addition has increased, alongside an improvement in quality, thanks to the increased professionalism in the mango sector. As a result, mango exports to the European Union went up from $280 \mathrm{t}$ in 1998 to $6,410 \mathrm{t}$ in 2006 [2] to rank Senegal in second place to Côte d'Ivoire. Despite this, improving the quality side of mango production remains a major objective because production is penalized by the considerable damage caused by fruit flies (Diptera, Tephritidae) even though there is a recurring pathogen complex in Niayes. These Diptera cause estimated 30$50 \%$ damage in the Niayes region and 60\% in the Casamance [3].

Only limited studies have been carried out in Senegal on fruit flies. A preliminary inventory of fruit flies in mango orchards was made as part of the joint study by the Comité de Liaison Europe-Afrique-CaraïbesPacifique (COLEACP), the Centre de coopération internationale en recherche agronomique pour le développement (CIRAD), the Centre Régional de Recherche en Ecotoxicologie et de Sécurité Environnementale (CERES) and the Direction de la Protection des Végétaux (DPV) that identified 18 species; ten of which were Ceratitis species, six species of Dacus and two of Bactrocera [4]. These last two pest species of great economic importance were identified as Bactrocera cucurbitae (Coquillett) on crops of Cucurbitaceae and Bactrocera invadens Drew Tsuruta \& White on fruit tree crops, while the main Ceratitis species were Ceratitis cosyra (Walker) and Ceratitis silvestrii Bezzi [4]. Before B.invadens arrived in Africa, most fruit infestations recorded in West Africa were linked to C. cosyra and C. capitata (Wiedemann) [5, 6], but this situation changed completely after. The first studies on the hosts of B. invadens were carried out in East Africa [7, 8] and in West [9] and Central [10] Africa.

In our study zone, mango and citrus are the main fruits farmed, with, to a much lesser extent, papaya, guava and banana. The plantations are characterized by the presence of both traditional and intensive orchards. The traditional orchards are essentially dedicated to supplying the home market. The growers try to phase their production to reduce the pathogen risks and to overcome new commercial challenges, so they cultivate several genera, species and varieties of fruit alongside each other on their plots. Irrigation is necessary because the dry season lasts nearly nine months from October to mid-July. Besides the commercial goals, orchard composition is influenced by irrigation capacity.

The intensive orchards are dedicated to exporting mangoes so the blocks contain single species and single varieties grafted on Kent and, less commonly, on Keitt. These exporting producers must have at least 60 ha to be able to send their production for export only. Cropping is mechanized and agrochemical applications follow the specifications demanded to meet certification (GlobalGap, biological agriculture, etc.).

The non-growing exporters collect their mangoes from small growers, as do some exporting producers who need to top up their shipments when their own production falls short. The advent of certification and related higher buying prices have encouraged growers to produce under controlled management for exporting themselves rather than for producing fruit for collection.

The study zone is characterized by scattered orchards in artificial forest stands comprising species to protect the water-holding depressions (Casuarina equisetifolia Forst. and Eucalyptus sp.) and either self-reproducing fruit species (Annona senegalensis Pers.) or introduced trees such as Terminalia catappa L. or Achras sapota L. The naturalized fruit trees are relatively less 
significant both in terms of species and numbers than cultivated fruit trees.

Our study focused mainly on the fruit fly seasonality in different mango and citrus cultivars of commercial interest. A range of secondary host plants was also looked at, such as the Solanaceae (Lycopersicon esculentum Mill., Capsicum annuum L., Capsicum frutescens L.), the Cucurbitaceae [Cucumus sativus L., Cucumus melo L., Citrullus lanatus (Thunb.) Matsum. \& Nakai.] and other plants that might cause fluctuations in the Tephritidae populations of the orchards. This study focused particularly on establishing the influence of parameters such as the mango flowering period, variety, fruit location (on the tree or the ground), maturation stage (mature, immature), physiological state (dropped before maturity, damaged or senescent), color and size.

\section{Materials and methods}

\subsection{Study sites}

The study was carried out in Senegal, in the Niayes zone and the Thiès Plateau, in 19 orchards chosen by virtue of their accessibility, management, species and varietal diversity, and for the availability of fruit samples (table I).

Within Niayes, fourteen orchards were picked in nine localities: Notto Gouye Diama, Keur Séga, Bayakh, Sangalkam, Keur Ndiaye Lô, Keur Moussa, Gorom II and Sébikotane. On the Thiès Plateau, the study took place in five orchards in Peykouck, Pout and Sindia (figure 1).

The Niayes zone, which stretches between $17^{\circ} 26^{\prime}$ and $16^{\circ} 15^{\prime}$ long. W and $14^{\circ}$

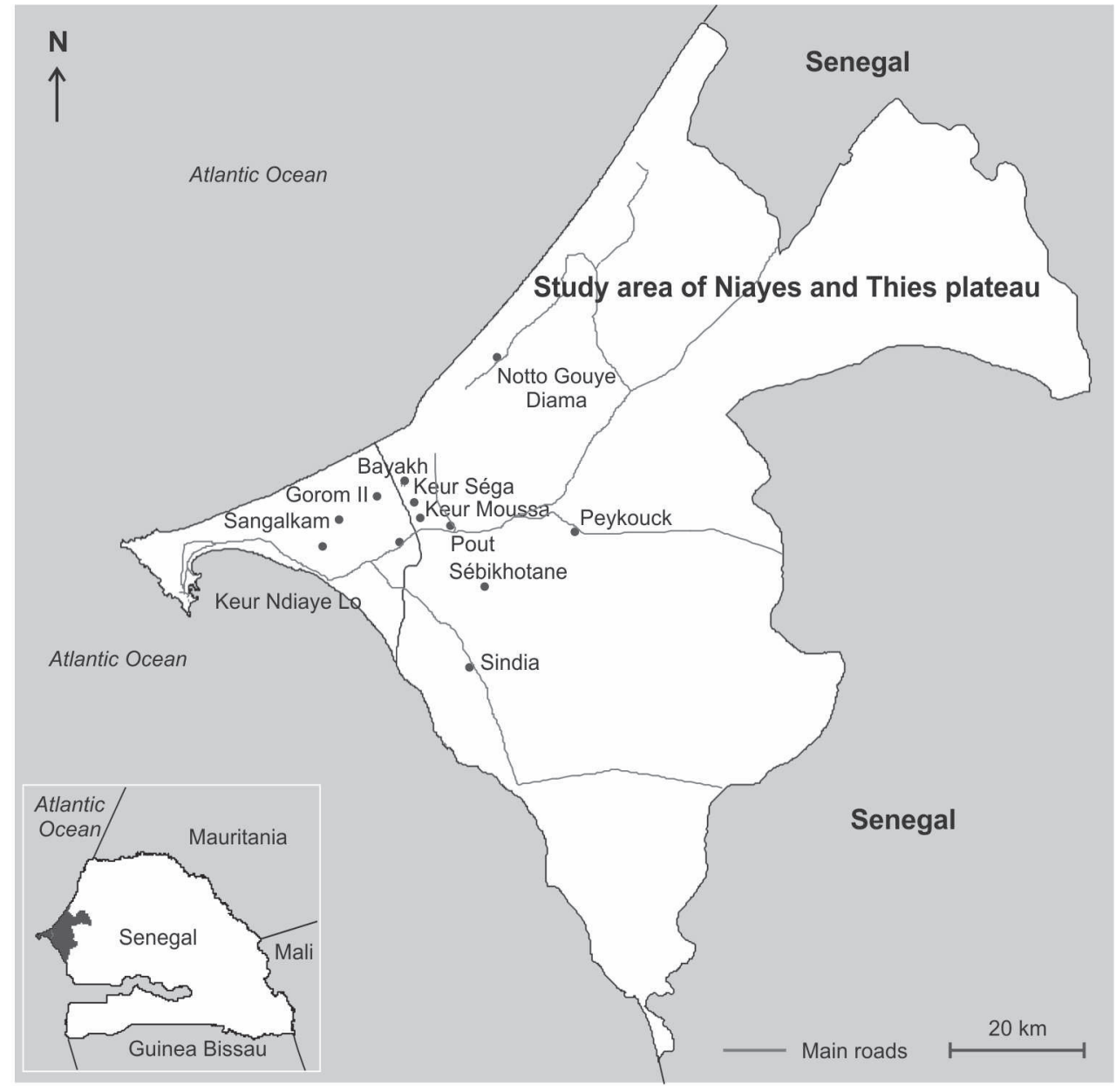

Figure 1.

Map of the orchard sites in the Niayes and Thiès plateau zones, in Senegal, where fruits were sampled for identifying fruit fly seasonality. 


\section{Table I.}

Locations of 19 orchards studied for identifying fruit flies present on fruit trees in the Niayes zone and the Thiès Plateau, in Senegal.

\begin{tabular}{|c|c|c|c|}
\hline Locations & $\begin{array}{l}\text { Number } \\
\text { of orchards }\end{array}$ & $\begin{array}{l}\text { Latitude } \\
\text { (N) }\end{array}$ & $\begin{array}{l}\text { Longitude } \\
\text { (W) }\end{array}$ \\
\hline \multicolumn{4}{|l|}{ Niayes zone } \\
\hline \multirow[t]{4}{*}{ Notto gouye Diama } & 4 & $14^{\circ} 58^{\prime} 32.3^{\prime \prime}$ & $17^{\circ} 01^{\prime} 36.2^{\prime \prime}$ \\
\hline & & $14^{\circ} 58^{\prime} 19.4^{\prime \prime}$ & $17^{\circ} 01^{\prime} 30.3^{\prime \prime}$ \\
\hline & & $14^{\circ} 59^{\prime} 05.3^{\prime \prime}$ & $17^{\circ} 00^{\prime} 17.2^{\prime \prime}$ \\
\hline & & $14^{\circ} 58^{\prime} 20.3^{\prime \prime}$ & $17^{\circ} 00^{\prime} 10.3^{\prime \prime}$ \\
\hline Sangalkam & 1 & $14^{\circ} 34^{\prime} 51.9^{\prime \prime}$ & $17^{\circ} 02^{\prime} 24.7^{\prime \prime}$ \\
\hline \multirow[t]{2}{*}{ Keur Séga } & 2 & $14^{\circ} 58^{\prime} 18.9^{\prime \prime}$ & $17^{\circ} 00^{\prime} 07.8^{\prime \prime}$ \\
\hline & & $14^{\circ} 58^{\prime} 08.8^{\prime \prime}$ & $17^{\circ} 00^{\prime} 09.2^{\prime \prime}$ \\
\hline Bayakh & 1 & $14^{\circ} 49^{\prime} 57.8^{\prime \prime}$ & $17^{\circ} 13^{\prime} 71.5^{\prime \prime}$ \\
\hline \multirow[t]{2}{*}{ Sébikotane } & 2 & $14^{\circ} 45^{\prime} 44.7^{\prime \prime}$ & $17^{\circ} 08^{\prime} 46.6^{\prime \prime}$ \\
\hline & & $14^{\circ} 45^{\prime} 45.6^{\prime \prime}$ & $17^{\circ} 09^{\prime} 07.3^{\prime \prime}$ \\
\hline \multirow[t]{2}{*}{ Keur Moussa } & 2 & $14^{\circ} 46^{\prime} 29.3^{\prime \prime}$ & $17^{\circ} 07^{\prime} 31.5^{\prime \prime}$ \\
\hline & & $14^{\circ} 46^{\prime} 29.8^{\prime \prime}$ & $17^{\circ} 07^{\prime} 29.9^{\prime \prime}$ \\
\hline Gorom II & 1 & $14^{\circ} 09^{\prime} 07.3^{\prime \prime}$ & $17^{\circ} 10^{\prime} 00.8^{\prime \prime}$ \\
\hline Keur Ndiaye Lo & 1 & $14^{\circ} 44^{\prime} 53.7^{\prime \prime}$ & $16^{\circ} 57^{\prime} 12.1^{\prime \prime}$ \\
\hline \multicolumn{4}{|l|}{ Thiès Plateau } \\
\hline Peykouck & 1 & $14^{\circ} 45^{\prime} 56.7^{\prime \prime}$ & $16^{\circ} 53^{\prime} 28.1^{\prime \prime}$ \\
\hline Pout & 1 & $14^{\circ} 45^{\prime} 37.4^{\prime \prime}$ & $17^{\circ} 03^{\prime} 18.6^{\prime \prime}$ \\
\hline \multirow[t]{3}{*}{ Sindia } & 3 & $14^{\circ} 34^{\prime} 13.0^{\prime \prime}$ & 1702 '39.9" \\
\hline & & $14^{\circ} 34^{\prime} 52.3^{\prime \prime}$ & 17 02'23.6" \\
\hline & & $14^{\circ} 34^{\prime} 08.3^{\prime \prime}$ & 17 03'17.0" \\
\hline
\end{tabular}

to $15^{\circ} 56^{\prime}$ lat. $\mathrm{N}$, lies between the $500-\mathrm{mm}$ isohyet in the south towards Dakar and the 350-mm isohyet in the north towards SaintLouis. The zone is characterized by non-lessive tropical ferruginous soils, crude mineral soils, red-brown soils, halomorphic soils, and pseudo-gley mineral soils in the lowlands [11]. The surface layer varies down to $30 \mathrm{~m} \mathrm{[12]}$. The Niayes zone is part of the Sahel-Sudanian region. Its vegetation is influenced by the topography, the soils present and water availability. Plant cover is dominated by plantations (Casuarina equisetifolia Forst.) protecting basins, and naturally occurring clumps of Elaeis guinensis Jacq., Cocos nucifera L., Mezoneurum benthamianum Baill. and hygrophilic species [Nymphaea lotus L., Phragmites vulgaris (Lam.) Druce., Alchornea cordifolia (S. et Th.) Müll. Arg.] on the highly humid lowlands; by Parinari macrophylla Sabine, Faidherbia albida (Del.) Chev., Acacia 
seyal Del., Balanites aegyptiaca (L.) Del.; with Euphorbiaceae, Combretaceae and graminaceous plants such as Cenchrus biflorus Roxb., Andropogon sp., Eragrostis sp. on the red ocher dunes (Ogolien); and by Opuntia tuna (L.) Mill., Maytenus senegalensis (Lam.) Exell. on the yellow and white dunes [13].

The Thiès Plateau, with substantial mango plantations, belongs to Senegal's Groundnut Basin where the soils are tropical ferruginous, either gray-brown podzolic or slightly gray-brown podzolic. This results in a pedoclimatic zone of continental rise and plains with a marno-calcareous soil, in turn creating a series of hydromorphic ferruginous soils over marno-calcareous colluvial material with either sandy-clay or clayey-sand surface horizons. The water table is tapped easily, while rainfall is from $400 \mathrm{~mm}$ up to $600 \mathrm{~mm}$. Vegetation comprises mostly Khaya senegalensis (Desr.) A. Juss. and Eucalyptus sp. in the plantations in Bandia, with natural stands in Pout, Thiès, Bandia and the communal reserve in Popenguine composed of Acacia seyal Del., Faidherbia albida (Del.) Chev., Acacia ataxacantha DC., Combretum sp., Borassus aethiopum Mart., Guiera senegalensis J.F. Gmel. and Adansonia digitata L. This fertile zone lends itself to reforestation and mixed cropping [14]. The mango varieties are sometimes the rootstock of polyembryonic varieties that self-disseminate, such as Boucodiékhal, Dieg bou gatt or Séwé, and sometimes grafted cultivars, the most frequently found of which were Kent, Keitt, Amélie and Paheri (known locally as Pêche). Cultivars such as Palmer, Haden and Colombo are encountered occasionally. But there are many intermediate levels between the big export-oriented plantations and the little orchards that cater for the local market: big plantations looking to the national or sub-regional markets; little orchards of Kent for sale to exporters or traders; the little mango plantations receiving little or no maintenance; or, on the other hand, the small plantations taking tremendous care with a range of strongly performing species and varieties, etc.

The varietal composition of orchards is one of the main differences between the tra- ditional and intensive. Traditional orchards are often bounded by hedges of Euphorbia turicali L., Euphorbia balsamifera Ait. or Capparis tomentosa Lam. Infrequent weed clearance encourages wild Cucurbitaceae such as Kedrostis hirtella Cogn., Momordica balsamina L., Momordica charantia L. or Collocynthus sp.

\subsection{Fruit tree species sampled}

The phenology of the fruit trees was surveyed to determine their production periods. Following the orchards surveyed, ten fruits per sample were collected weekly from April to December 2008, either from the ground or by picking from several fruit tree species, depending on their production periods. These fruit tree species were mango (Mangifera indica L.), citrus species [Citrus aurantium L., C. aurantifolia (Christm.) Swing., C. maxima L., C. paradisi Macfad., C. clementina Hort. Ex Tan., C. reticulata Blanco, C. limon (L.) Burm. F., C. sinensis (L.) Osbeck, C. deliciosa Tan., Fortunella japonica Swing., F. margarita Swing.], other introduced trees [Psidium guajava (L.), Eugenia uniflora L., Phoenix dactylifera L., Terminalia catappa L., Phyllanthus acidus (L.) Skeel.] and local species [Saba senegalensis (A. DC.) Pichon., Cordyla pinnata (Lepr.) Miln.-Red., Kedrostis birtella Cogn., Ziziphus mauritiana Lam., Sclerocarya birrea (A. Rich.) Hochst., Spondias mombin L., Capparis tomentosa Lam., Momordica balsamina L., Cucumus sativus L.]. Some species comprised several identified varieties, e.g., twenty-four varieties for Mangifera indica, six cultivars for Citrus aurantifolia, four cultivars for C.paradisi, and two cultivars for $C$. sinensis. The fruits from each sample were weighed and their dimensions were taken before being classed by size as $0-5 \mathrm{~cm}, 5-10 \mathrm{~cm}, 10-15 \mathrm{~cm}$ and $15-20 \mathrm{~cm}$. Classification also took account of color, fruit condition, sampling location and the flowering date of the mango.

\subsection{Fruit monitoring}

The weighed and classified fruits were incubated over a substrate of sieved coarse sand in pots firmly covered with cloth to prevent 
the escape of any larvae or imagoes as well as to keep out ants or spiders. The number of fruits in samples varied according to species and their on-site availability; so the average was (7.2 \pm 1.2$)$ fruits for mango, $(13.4 \pm 1.8)$ fruits for citrus, $(15.1 \pm 1.1)$ fruits for cashew, and (25.5 \pm 1.0$)$ fruits for capers.

After one to three weeks of incubation, any pupae found were placed in Petri dishes and their emergence monitored so they could be identified and counted by species and sex, and indexed by sample following designated parameters.

The various fruit samples were collected in the selected orchards from April to December 2008 to cover the flowering, setting, bulking and maturing of the mangoes from one production season through to the onset of flowering in the next. The observations made during field sampling covered the weight and size of fruit, its condition; the number of pupae extracted per sample, the number of Tephritidae by species and sex, and the number of parasitoids on the pupae.

\subsection{Statistical analyses}

The data were processed using Microsoft Excel and XL Stat for the analysis of variance and mean comparisons. The ANOVAs for mango in relation to emergence of $B$. invadens and C. cosyra took particular account of various parameters such as the flowering pattern prior to mango production, where sampling was taken from, size, skin color, condition and variety. The percentage incidence of B. invadens and $C$. cosyra was calculated for each mango variety using the formula $\{[\mathrm{a} /(\mathrm{a}+\mathrm{b})] \times 100\}$ in which $a$ is the number of individuals of $B$. invadens and $b$ is the number of individuals of $C$. cosyra in a sample.

\section{Results}

\subsection{Production periods for orchard fruit plants}

Fruits are present in the orchards from April to December (table II). These are fruits both from cultivated and naturally occurring plants. Therefore, Carica papaya, Fortunella sp., Citrus paradisi and Momordica balsamina bear fruit throughout the duration of the study period while others have seasonal production only: Mangifera indica, Capparis tomentosa, etc.

\subsection{Tephritidae species found in the host fruits}

The orchard visits collected a total of 7,290 fruits of mixed species, weighing $663.2 \mathrm{~kg}$ equally distributed between Niayes and the Thiès Plateau, 59\% of which were mangoes and $28 \%$ citrus. The remaining $13 \%$ were the products of the other cultivated and self-seeded plants. The pot incubation of these fruits produced 37,276 pupae from which emerged 22,972 fruit flies subdivided into $52 \%$ females and $48 \%$ males. At the same time, the emergence of 122 parasitoids (Braconidae) of fruit flies was recorded. The emergence of fruit fly species by host plant was assessed (table III). Certain species of Tephritidae, i.e., Bactrocera invadens, B. cucurbitae, Dacus spp., Ceratitis capitata, C. cosyra and Carpomyia spp., were found on several host plants. The polyphagous species $B$. invadens emerged from many of the fruit tree species found in and around the orchards in Niayes and on the Thiès Plateau, including Mangifera indica (24 varieties), Anacardium occidentale L., Sclerocarya birrea (Anacardiaceae), Terminalia catappa (Combretaceae), Capparis tomentosa (Capparidaceae), Ziziphus mauritiana (Rhamnaceae), Psidium guajava, Eugenia uniflora (Myrtaceae), Annona muricata (Annonaceae), Kedrostis birtella (Cucurbitaceae), Carica papaya (Caricaceae), Cordyla pinnata (Cesalpiniaceae), Phoenix dactylifera (Palmaceae), Achras sapota (Sapotaceae), Saba senegalensis (Apocynaceae), Passiflora edulis Sims (Passifloraceae) and 13 citrus species. Among the citrus, the genus Fortunella showed up as more susceptible to $B$. invadens than members of the genus Citrus $(P<0.0001)$ such as $C$. aurantium, C. aurantifolia, C. clementina, C. deliciosa, C. reticulata, $C$. limon, $C$. paradisi, $C$. sinensis and C. maxima (Rutaceae). This susceptibility was more marked for $F$. japonica than for F. margarita. 
Table II.

Production periods from April to December 2008 for the main fruit trees studied for identifying fruit flies present in orchards of the Niayes and Thiès Plateau zones, in Senegal.

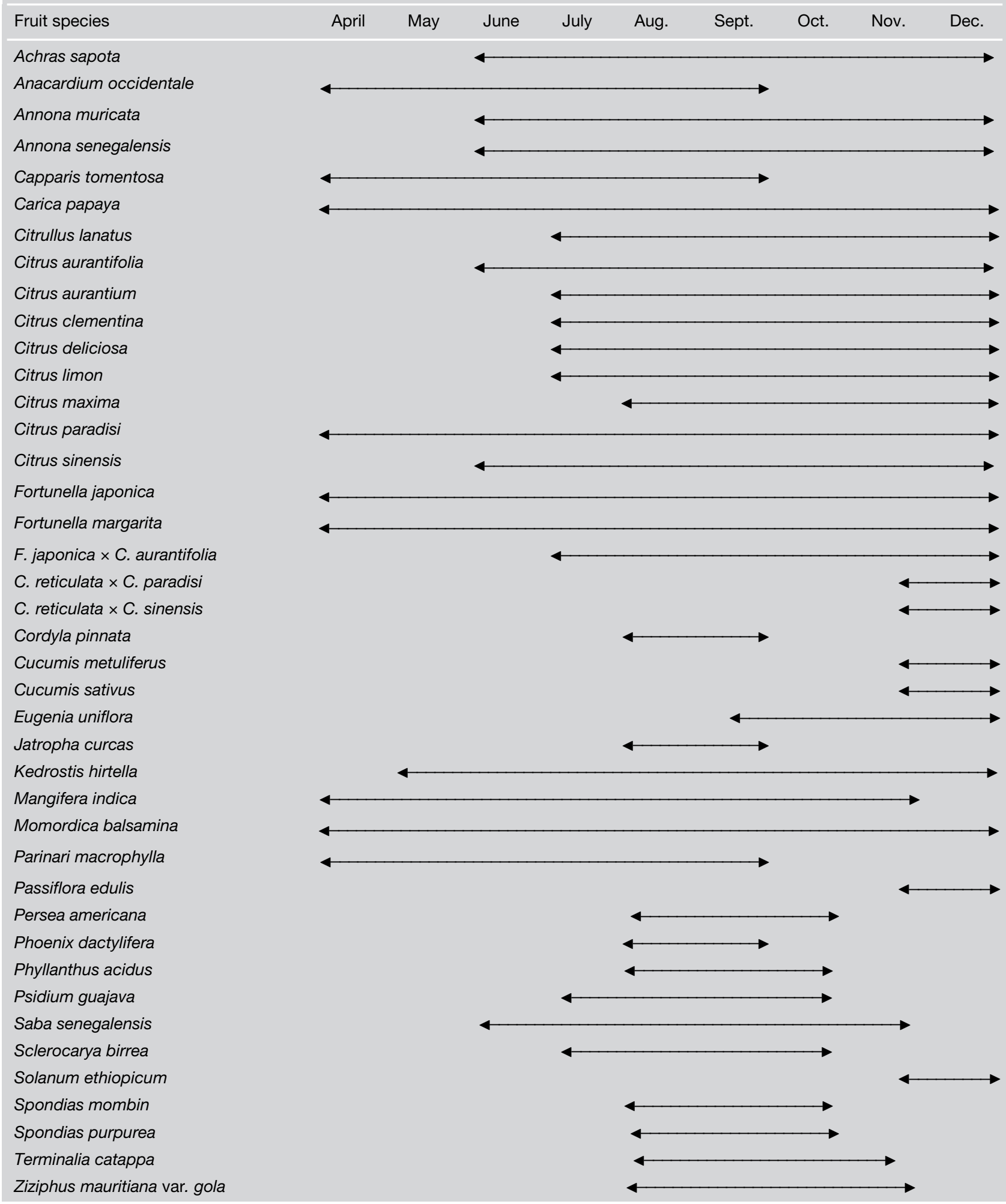


Table III.

Breakdown of Tephritidae species by host plant found in orchards of the Niayes and Thiès Plateau zones, in Senegal.

\begin{tabular}{lcccccccccc} 
Host plants & $\begin{array}{c}\text { Bactrocera } \\
\text { invadens }\end{array}$ & $\begin{array}{c}\text { Ceratitis } \\
\text { cosyra }\end{array}$ & $\begin{array}{c}\text { Ceratitis } \\
\text { capitata }\end{array}$ & $\begin{array}{c}\text { Carpomyia } \\
\text { sp. }\end{array}$ & $\begin{array}{c}\text { Capparimyia } \\
\text { bipustulata }\end{array}$ & $\begin{array}{c}\text { Dacus } \\
\text { sp. }\end{array}$ & $\begin{array}{c}\text { Bactrocera } \\
\text { cucurbitae }\end{array}$ & $\begin{array}{c}\text { Ceratitis } \\
\text { punctata }\end{array}$ & $\begin{array}{c}\text { Ceratitis } \\
\text { bremii }\end{array}$ & $\begin{array}{c}\text { Quantity of } \\
\text { fruits (kg) }\end{array}$ \\
\hline Achras sapota & $*$ & $*$ & - & - & - & - & - & - & - & -
\end{tabular}

10.9

occidentale

Annona muricata

Annona senegalensis

Capparis tomentosa

Capsicum annuum

Carica papaya

Citrullus lanatus

Citrus aurantifolia

Citrus aurantium

Citrus clementina

Citrus deliciosa

Citrus limon

Citrus maxima

Citrus paradisi

Citrus sinensis

Cordyla pinnata

Cucumus metiflorus

Cucumus sativus

Eugenia uniflora

Fortunella japonica

Fortunella margarita

Jatropha curcas

Kedrostis hirtella

F. japonica $\times$

C. aurantifolia (limequat)

Mangifera indica

Momordica balsamina

Parinari macrophylla

Passiflora edulis

Persea americana

Phoenix dactylifera

Phyllanthus acidus

Psidium guajava

Citrus reticulata $x$

C. paradisi $=$ Tangélo

Citrus reticulata $x$

C. sinensis = Tangor

Terminalia catappa

Saba senegalensis

Sclerocarya birrea

Solanum aethiopicum

Spondias mombin

Ziziphus mauritiana

var. gola

Average emergence values for the collected fruit samples: * $\leq 100$ individuals per $\mathrm{kg}$ of fruits, ${ }^{* *} 100<\times<200$ individuals per kg of fruits, ${ }^{\star \star \star}$ more than 200 individuals per kg of fruits. 
The polyphagous species Ceratitis cosyra emerged from the fruits of Achras sapota, Citrus clementina, Kedrostis hirtella, Mangifera indica, Capparis tomentosa, Sclerocarya birrea and Cordyla pinnata.

Ceratitis capitata emerged from the peppers C. annuum, Capparis tomentosa, and some citrus. Bactrocera cucurbitae and Dacus spp., which were plentiful on the flowers of Ziziphus mauritiana var. gola, emerged from the Cucurbitaceae such as Kedrostis birtella, Momordica balsamina, Cucumus sativus and Citrullus lanatus. However, other species of Tephritidae were retrieved from single host plants. This was the case for the monophagous species Ceratitis bremii (Guerin-Meneville), Ceratitis punctata (Wiedemann), Carpomyia sp. and Capparimiya bipustulata Bezzi, which were retrieved from, respectively, Cordyla pinnata, Achras sapota, Ziziphus mauritiana var. gola and Capparis tomentosa.

Certain fruit trees, which harbored several species of fruit fly, were also infested by Bactrocera invadens. These were Capparis tomentosa, which hosted Capparimyia bipustulata on top of $B$. invadens, Ceratitis cosyra and Ceratitis capitata; Ziziphus mauritiana var. gola, which hosted B. invadens on top of Carpomyia sp.; C. annuum, which harbored both $C$. capitata and B. invadens; Mangifera indica hosted B. invadens and C. cosyra; while, among the citrus, Citrus clementina hosted B. invadens and C. cosyra; and Citrus paradisi, Fortunella margarita and F. japonica harbored B. invadens and C. capitata.

With the infestations of Ziziphus mauritiana var. gola in particular, pupation of the larvae of Carpomyia sp. often took place inside the fruit in a cavity tunneled next to the pit so that the fruit looked outwardly healthy. However, fruit infested by 510 Bactrocera invadens larvae putrefied quickly and more seriously than that affected by the autochthonous Carpomyia sp. With Capparis tomentosa, on the other hand, the number of Capparimya bipustulata is significantly greater than for Bactrocera invadens or Ceratitis capitata $(P<0.0003)$.

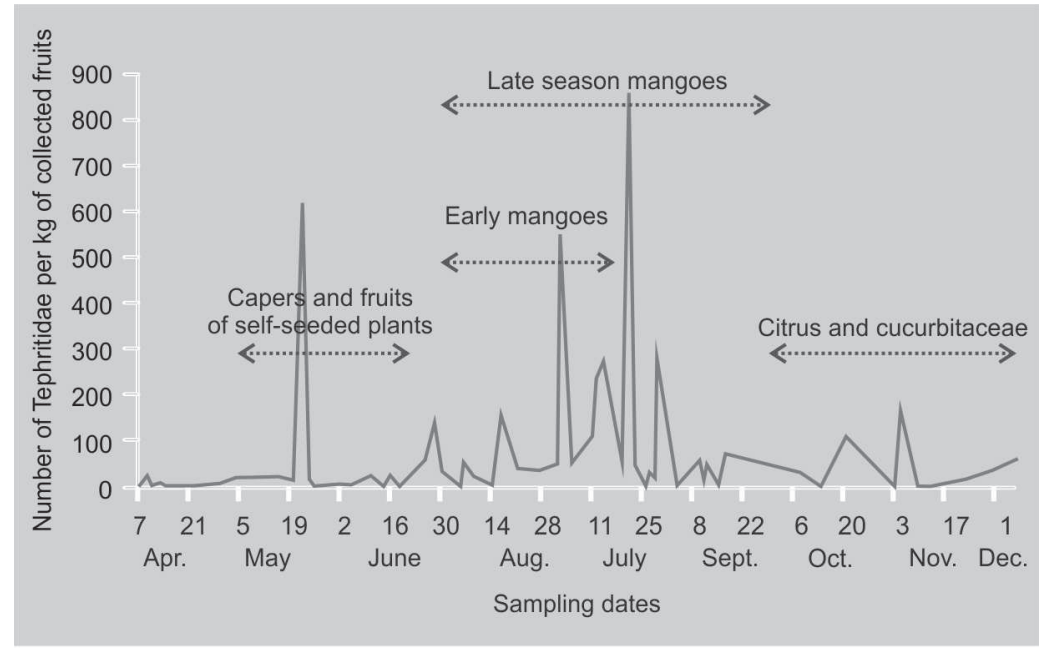

\subsection{Relationship between Tephritidae emergence from the sampled fruit and maturation period of the main host plants}

The number of flies emerging from the collected fruits was studied as a function of time and the emergence dynamics correlated to the main host plants' maturation periods (figure 2). This shows that the level of fruit fly emergence from the collected fruits varies in time as a function of the maturing periods of the potential fruit hosts. The peaks are more significant for the maturation of mangoes and relatively significant during citrus maturation.

\subsubsection{Dynamics and scale of Tephritidae emergence between orchards on the Thiès Plateau}

The results obtained relating to the emergence of the various species of fruit fly were compared as a function of type of orchard, season and site, both in Niayes and on the Thiès Plateau. Studying the progress of $B$. invadens and C. cosyra emergence for an orchard in Pout (traditional orchard) and another in Sindia (modern orchard) on the Thiès Plateau (figure 3), it can be seen that, for the Thiès Plateau, emergence between April and mid-July is greater in the traditional type of orchard in Pout than in the modern orchard in Sindia, but this changed later when emergence increased in Sindia. Between April and July, C. cosyra is the
Figure 2.

Emergence dynamics of fruit flies and the production periods of the main hosting fruit trees in orchards of the Niayes and Thiès plateau zones (2008, Senegal). 


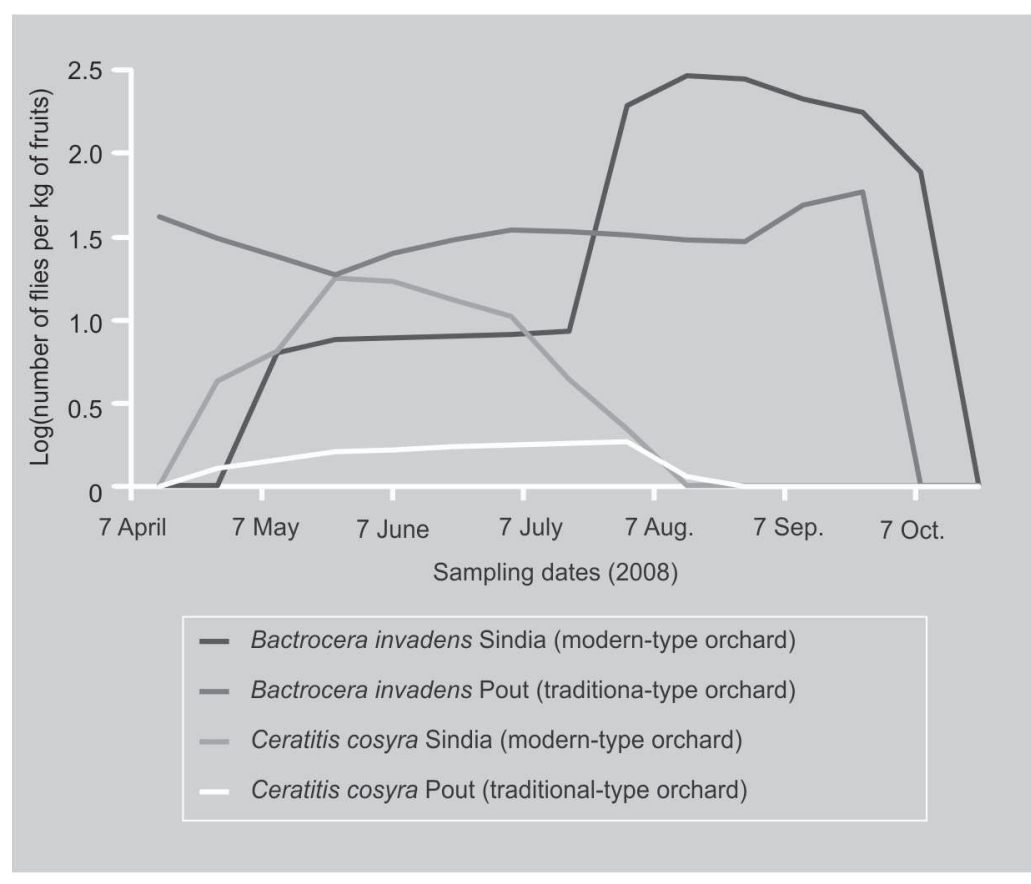

Figure 3.

Emergence dynamics for Bactrocera invadens and Ceratitis cosyra in a traditionaltype orchard (Pout) and a modern-type orchard (Sindia) on the Thiès Plateau, Senegal.

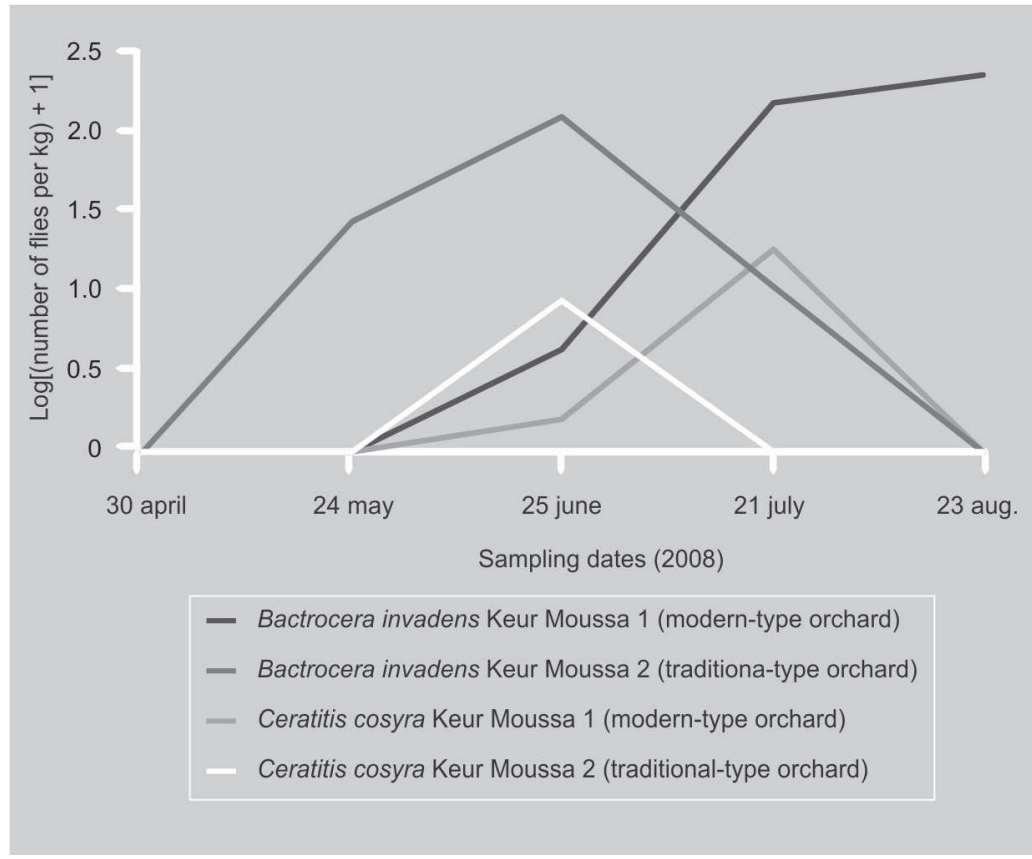

Figure 4.

Emergence dynamics for Bactrocera invadens and Ceratitis cosyra in Keur Moussa in a traditional-type and in a modern-type orchard in the Niayes zone (Senegal). dominant species in Sindia, while $B$. invadens dominates in Pout. However, $B$. invadens becomes six times more significant in Sindia from July onwards than in Pout. Nevertheless, emergence of $B$. invadens is greater than that of $C$. cosyra $(P<0.001)$ on all the sampling dates in Pout. Ceratitis cosyra emergence appears to peak earlier (between May and June) than that of B. invadens.

\subsubsection{Dynamics and scale of emergence of Tephritidae between orchards in Niayes}

The dynamics of the emergence of Tephritidae from fruits collected in the Niayes orchards were analyzed to compare several sites of both traditional-type and moderntype orchards.

The emergence dynamics for $B$. invadens and $C$. cosyra in Keur Moussa for a traditional orchard and a modern orchard showed critical levels of fruit fly emergence in the traditional orchard between April and mid-July, but the modern-type orchard reached its greatest levels of emergence after this date (figure 4). Emergence of $B$. invadens was greater than that of $C$ cosyra in both types of orchard $(P<0.001)$. Among the various observations made across both types of orchard, we noted that populations of $B$. invadens were more precocious in the traditional type of orchard in having a peak outbreak at the end of June against the second two weeks of August for the modern-type orchard.

\subsubsection{Tephritidae emergence for different varieties of mango in the traditional and modern orchards}

A study comparing the emergence dynamics of the traditional orchard in Pout with that of the modern orchard in Sindia showed the population levels of $B$. invadens to be earlier to peak and more substantial in Pout than in Sindia between April and July $(P<0.049)$. Meanwhile, the $C$. cosyra emergence was greater for the modern orchard in Sindia than in the traditional orchard in Pout $(P<0.009)$. Therefore, emergence varied from one type of orchard to the other 


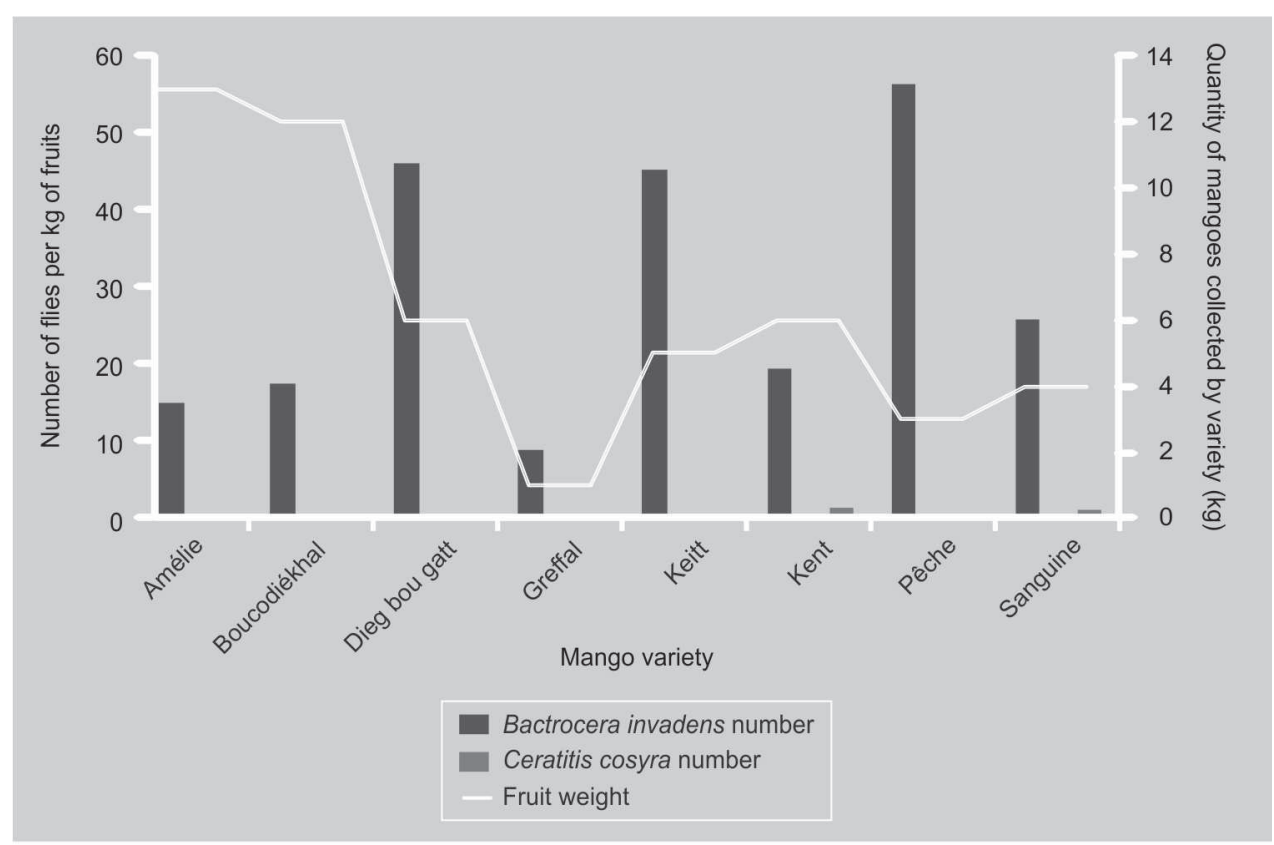

and also within those species present at the times in question.

\subsubsection{Traditional orchard in Pout}

The study also looked at variation in fruit fly species on the varieties of mango collected from each orchard. The number of Tephritidae per kg of fruits collected by mango variety and the quantity of fruit sampled for each variety show that local varieties (Boucodiékhal, Dieg bou gatt, Greffal) and grafted trees (Amélie, Keitt, Kent, Pêche and Sanguine) grown simultaneously in the traditional orchard in Pout were infested (figure 5). The quantity of fruits collected was greater for Amélie and Boucodiékhal but all the varieties were more infested by B. invadens than by $C$. cosyra $(P<0.0001)$. The varieties Pêche, Dieg bou gatt, Keitt, Sanguine, Kent and Boucodiékhal seemed to have greater infestations than Amélie and Greffal $(P<0.001)$. There was no significant difference between the varieties Keitt and Dieg bou gatt, on one hand, and between Kent and Boucodiékhal, on the other hand $(P=0.719)$, although $B$. invadens emergence remained greater than that of C. cosyra $(P<0.0001)$.

\subsubsection{Modern orchard in Sindia}

A block in the Sindia orchard containing several mango varieties was monitored from before the maturation period of the early varieties through to the end of the late types Boucodiékhal, Keitt and Kent. The average number of Tephritidae by species and per $\mathrm{kg}$ of fruits collected of each variety in this orchard and the total quantity of fruits noted for each mango variety showed that the varieties Boucodiékhal, Haden and Valencia were significantly more infested than the cultivars Keitt, Kent, Irwin, Heidy, Early Gold, Pêche and Divine, while Amélie, David Haden, Sensation and Colombo were classed as intermediate (figure 6). The percentage infestation by $B$. invadens and by C. cosyra was calculated for each variety, revealing that the varieties David Haden, Keitt, Colombo, Boucodiékhal and Heidy were infested in more than $75 \%$ of instances by $B$. invadens, while $C$. cosyra infested the varieties Divine, Irwin, Valencia, Early Gold, Pêche and Haden in more than $75 \%$ of cases.

In the modern orchard in Sindia, there is no significant difference in the numbers of C. cosyra emerging and those of
Figure 5.

Number of Bactrocera invadens and Ceratitis cosyra counted by $\mathrm{kg}$ of fruits and by mango variety in a traditional-type orchard in Pout (Thiès Plateau, Senegal). 
Figure 6.

Number of Bactrocera invadens and Ceratitis cosyra counted by $\mathrm{kg}$ of fruits and by mango variety in a modern-type orchard in Sindia (Thiès Plateau, Senegal).

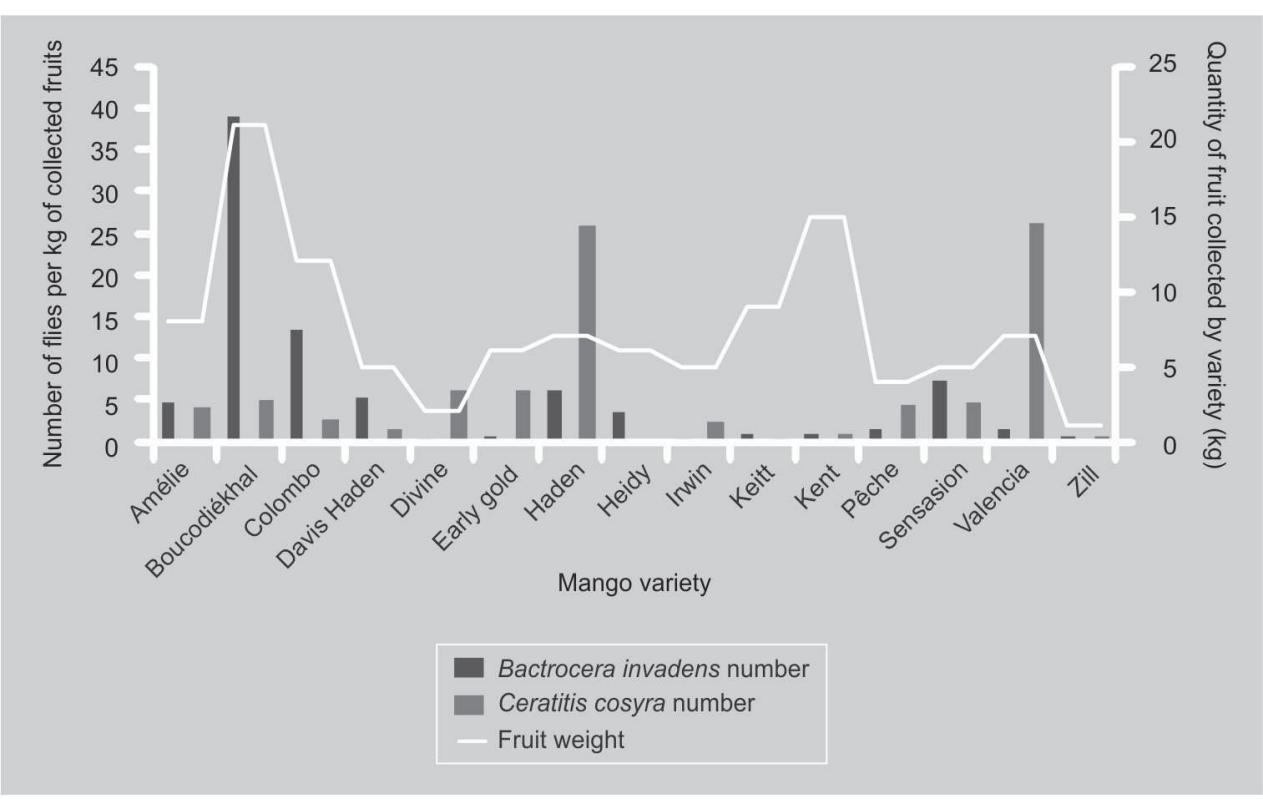

B. invadens $\quad(P=0.942) . \quad$ However, $B$. invadens emergence numbers are significantly more substantial than for C. cosyra in the traditional-type orchard in Pout $(P<0.003)$. On the other hand, where $C$ cosyra is implicated in mango infestations, the emergence of $C$. cosyra is significantly greater in Sindia than in Pout $(P<0.034)$. Looking at the varieties, $C$. cosyra emergence is significantly greater with Valencia and Haden compared with Divine, Early Gold, Boucodiékhal, Irwin, Sensation, Pêche, Colombo, Amélie, David Haden, Sanguine, Kent, Keitt, Greffal, Dieg bou gatt and Heidy. This is not the case for the infestations linked to B.invadens, which are of greater significance in the traditional orchard in Pout than in the modern-type one in Sindia $(P<0.0001)$. However, there is no significant difference between mango varieties in these orchards in terms of the emergence of B. invadens.

\subsubsection{Influence of fruit condition on the variability of Tephritidae emergence from citrus and mango}

The physiological and morphological parameters, such as fruit condition, size and color, of commercial host fruits such as citrus and mango trees were studied.

\subsubsection{Citrus}

Studies on the impact of fruit condition on Tephritidae emergence from citrus fruits showed that, among the citrus species, the genus Fortunella was the most infested by $B$. invadens when compared with members of the genus Citrus $(P<0.0001)$, i.e., $C$. aurantium, C. aurantifolia, C. clementina, C. deliciosa, C. reticulata, C. limon, $C$. paradisi and C. sinensis (table IV). Infestation was greater for $F$. japonica than for $F$. margarita. On the other hand, the limequat drawn from crossing Fortunella sp. $\times$ Citrus sp. was significantly less infested than $F$. japonica $(P<0.009)$ but there is no significant difference between this hybrid and $F$. margarita $(P=0.323)$.

As well as species, the number of Tephritidae emerging from collected citrus fruits varied according to cultivar and fruit condition (table $I V$ ). With the exception of Citrus limon, where there were more Tephritidae from rotting fruit, newly ripe fruits of the various citrus produced the highest emergence. The lowest emergence was from aborted fruits. For Citrus aurantifolia, Tahiti lime was the most infested in contrast to either Yuma lime or spineless limes, which produced no fruit flies. Among the C.paradisi grapefruits, the cultivar Orobianco was the most infested by 
Table IV.

Impact of the development stage of the fruit on the Tephritidae emergence in citrus fruits in orchards of the Niayes and Thiès Plateau zones, in Senegal.

\begin{tabular}{|c|c|c|c|c|c|c|}
\hline \multirow[t]{2}{*}{ Citrus } & \multicolumn{2}{|c|}{$\begin{array}{l}\text { Tephritidae (emerged flies) } \\
\text { per kg }\end{array}$} & \multirow[t]{2}{*}{$\begin{array}{l}\text { Bactrocera } \\
\text { invadens }\end{array}$} & \multirow[t]{2}{*}{$\begin{array}{c}\text { Ceratitis } \\
\text { cosyra }\end{array}$} & \multirow[t]{2}{*}{$\begin{array}{l}\text { Ceratitis } \\
\text { capitata }\end{array}$} & \multirow{2}{*}{$\begin{array}{c}\text { Quantity } \\
\text { of fruits sampled } \\
(\mathrm{kg})\end{array}$} \\
\hline & $\begin{array}{l}\text { General } \\
\text { means }\end{array}$ & $\begin{array}{c}\text { Partial means } \\
\text { per development stage }\end{array}$ & & & & \\
\hline Fortunella japonica & $240.00 \mathrm{a}$ & - & 239.6 & 0 & 0.4 & 3.032 \\
\hline ripe & - & 240.0 & 239.6 & 0 & 0.4 & 3.032 \\
\hline Fortunella margarita & $115.50 \mathrm{ab}$ & - & 95.8 & 0 & 19.7 & 8.159 \\
\hline ripe & - & 115.5 & 95.8 & 0 & 19.7 & 8.159 \\
\hline Limequat & $86.5 \mathrm{~b}$ & - & 86.5 & 0 & 0 & 3.959 \\
\hline ripe & - & 86.5 & 86.5 & 0 & 0 & 3.959 \\
\hline Citrus aurantium & $61.40 \mathrm{bc}$ & - & 61.4 & 0 & 0 & 6.733 \\
\hline ripe & - & 76.8 & 76.8 & 0 & 0 & 5.533 \\
\hline senescent & - & 0 & 0 & 0 & 0 & 1.200 \\
\hline Citrus deliciosa & $26.20 \mathrm{c}$ & - & 26.2 & 0 & 0 & 14.326 \\
\hline aborted & - & 0 & 0 & 0 & 0 & 0.556 \\
\hline ripe & - & 29.4 & 29.4 & 0 & 0 & 13.033 \\
\hline senescent & - & 0 & 0 & 0 & 0 & 0.737 \\
\hline Tangélo & $16.50 \mathrm{c}$ & - & 16.5 & 0 & 0 & 2.591 \\
\hline ripe & - & 16.5 & 16.5 & 0 & 0 & 2.591 \\
\hline Citrus clementina & $15.30 \mathrm{c}$ & - & 14.6 & 0.7 & 0 & 11.781 \\
\hline aborted & - & 0 & 0 & 0 & 0 & 0.171 \\
\hline fissured & - & 0 & 0 & 0 & 0 & 0.275 \\
\hline ripe & - & 18.9 & 18.1 & 0.9 & 0 & 9.992 \\
\hline senescent & - & 0 & 0 & 0 & 0 & 1.343 \\
\hline Citrus aurantifolia & $15.00 \mathrm{c}$ & - & 15.0 & 0 & 0 & 34.431 \\
\hline aborted & - & 0 & 0 & 0 & 0 & 0.377 \\
\hline Yuma lime & - & 0 & 0 & 0 & 0 & 0.377 \\
\hline ripe & - & 17.3 & 17.3 & 0 & 0 & 31.202 \\
\hline IAC lime & - & 2.8 & 2.8 & 0 & 0 & 4.741 \\
\hline Mexican lime & - & 2.6 & 2.6 & 0 & 0 & 8.681 \\
\hline Spineless lime & - & 0 & 0 & 0 & 0 & 0.736 \\
\hline Tahiti lime & - & 37.8 & 37.8 & 0 & 0 & 16.461 \\
\hline Yuma lime & - & 0 & 0 & 0 & 0 & 0.583 \\
\hline senescent & - & 2 & 2 & 0 & 0 & 2.852 \\
\hline IAC lime & - & 0 & 0 & 0 & 0 & 1.904 \\
\hline Tahiti lime & - & 6 & 6 & 0 & 0 & 0.948 \\
\hline Citrus sinensis & $13.80 \mathrm{c}$ & - & 13.8 & 0 & 0 & 11.785 \\
\hline aborted & - & 4.3 & 4.3 & 0 & 0 & 1.677 \\
\hline Hamelin & - & 13 & 13 & 0 & 0 & 0.451 \\
\hline Japanese orange & - & 0 & 0 & 0 & 0 & 1.226 \\
\hline ripe & - & 17 & 17 & 0 & 0 & 10.108 \\
\hline Hamelin & - & 20.2 & 20.2 & 0 & 0 & 6.256 \\
\hline Japanese orange & - & 13 & 13 & 0 & 0 & 3.852 \\
\hline
\end{tabular}


Table IV. (continued)

Impact of the development stage of the fruit on the Tephritidae emergence in citrus fruits in orchards of the Niayes and Thiès Plateau zones, in Senegal.

\begin{tabular}{|c|c|c|c|c|c|c|}
\hline \multirow[t]{2}{*}{ Citrus } & \multicolumn{2}{|c|}{$\begin{array}{c}\text { Tephritidae (emerged flies) } \\
\text { per kg }\end{array}$} & \multirow[t]{2}{*}{$\begin{array}{l}\text { Bactrocera } \\
\text { invadens }\end{array}$} & \multirow[t]{2}{*}{$\begin{array}{l}\text { Ceratitis } \\
\text { cosyra }\end{array}$} & \multirow[t]{2}{*}{$\begin{array}{l}\text { Ceratitis } \\
\text { capitata }\end{array}$} & \multirow{2}{*}{$\begin{array}{c}\text { Quantity } \\
\text { of fruits sampled } \\
(\mathrm{kg})\end{array}$} \\
\hline & $\begin{array}{c}\text { General } \\
\text { means }\end{array}$ & $\begin{array}{c}\text { Partial means } \\
\text { per development stage }\end{array}$ & & & & \\
\hline Citrus paradisi & $8.00 \mathrm{c}$ & - & 8.0 & 0 & 0.04 & 65.469 \\
\hline aborted & - & 0.10 & 0.1 & 0 & 0 & 9.343 \\
\hline Marsh & - & 0 & 0 & 0 & 0 & 0.230 \\
\hline Red blush & - & 0.25 & 0.25 & 0 & 0 & 5.528 \\
\hline Shambar & - & 0 & 0 & 0 & 0 & 3.585 \\
\hline ripe & - & 9.3 & 9.3 & 0 & 0.04 & 55.788 \\
\hline Marsh & - & 5 & 5 & 0 & 0 & 10.590 \\
\hline Orobianco & - & 14.2 & 14.2 & 0 & 0 & 15.582 \\
\hline Red blush & - & 8.1 & 7.9 & 0 & 0.2 & 7.807 \\
\hline Shambar & - & 8.6 & 8.6 & 0 & 0 & 21.809 \\
\hline senescent & - & 0 & 0 & 0 & 0 & 0.338 \\
\hline Red blush & - & 0 & 0 & 0 & 0 & 0.338 \\
\hline Citrus limon (Eureka) & $2.20 \mathrm{c}$ & - & 2.2 & 0 & 0 & 13.373 \\
\hline ripe & - & 1.7 & 1.7 & 0 & 0 & 9.704 \\
\hline senescent & - & 3.3 & 3.3 & 0 & 0 & 3.669 \\
\hline Tangor & $2.00 \mathrm{c}$ & - & 2 & 0 & 0 & 0.488 \\
\hline ripe & - & 2 & 2 & 0 & 0 & 0.488 \\
\hline Citrus maxima & $0.00 \mathrm{c}$ & - & 0 & 0 & 0 & 2.029 \\
\hline ripe & - & 0 & 0 & 0 & 0 & 2.029 \\
\hline
\end{tabular}

B. invadens. Ceratitis capitata was most commonly found among the C.paradisi grapefruits and kumquats, where $F$. margarita was more infested than $F$. japonica and $C$. paradisi $(P<0.001)$, contrary to what is observed with $B$. invadens. Ceratitis cosyra was found on C.clementina in particular. Fruit size had a significant effect on citrus infestations, e.g., fruits of C. deliciosa with a diameter between $5 \mathrm{~cm}$ and $10 \mathrm{~cm}$ demonstrated significantly greater levels of emergence than fruits with a diameter less than $5 \mathrm{~cm}(P<0.028)$.

\subsubsection{Mango}

For Mangifera indica orchards, fruit fly emergence varies according to the variety (table V). Across all the mangoes collected from 19 orchards, the varieties Séwé, Davis Haden, Kent, Keitt, Dieg bou gatt, Valencia, Boucodiékhal, Pêche, Sanguine, Colombo and Haden provided more than 20 fruit flies per $\mathrm{kg}$ of mangoes. The average $\mathrm{kg}$ of mangoes produced 25 specimens of $B$. invadens against two of $C$. cosyra. However, fruit condition at the moment of sampling influenced the numbers emerging from each variety. Mangoes with tunneling or other wounds had significantly greater infestation levels than aborted mangoes, ripe mangoes and those with advanced spoiling $(P<0.029)$. However, fruit condition on its own produced no significant differences among the greatest value infestations associated with C. cosyra in either mature or 
Table V.

Impact of the stage of development of the fruit on the Tephritidae emergence in mango varieties in orchards of the Niayes and Thiès plateau zones, in Senegal.

\begin{tabular}{|c|c|c|c|c|}
\hline \multirow{2}{*}{$\begin{array}{l}\text { Varieties } \\
\text { and condition of fruit }\end{array}$} & \multicolumn{3}{|c|}{ Number of flies per kg fruits } & \multirow{2}{*}{$\begin{array}{l}\text { Quantity of fruits } \\
\qquad(\mathrm{kg})\end{array}$} \\
\hline & Bactrocera invadens & Ceratitis cosyra & Total flies & \\
\hline Mangifera indica & 25.79 & 2.66 & 28.44 & 374.58 \\
\hline Séwé & 76.92 & 0.38 & 77.31 & 7.59 \\
\hline aborted & 166.00 & 0.00 & 166.00 & 2.24 \\
\hline ripe & 37.33 & 0.56 & 37.89 & 5.34 \\
\hline David Haden & 56.20 & 1.20 & 57.40 & 10.57 \\
\hline aborted & 0.00 & 0.00 & 0.00 & 1.10 \\
\hline ripe & 62.44 & 1.33 & 63.78 & 9.47 \\
\hline Kent & 34.64 & 0.66 & 35.30 & 75.52 \\
\hline aborted & 28.89 & 0.95 & 29.84 & 45.41 \\
\hline fissured & 43.00 & 0.00 & 43.00 & 2.14 \\
\hline ripe & 45.90 & 0.10 & 46.00 & 27.98 \\
\hline Keitt & 34.08 & 0.73 & 34.82 & 71.33 \\
\hline aborted & 20.90 & 0.85 & 21.74 & 38.84 \\
\hline fissured & 159.25 & 0.00 & 159.25 & 5.45 \\
\hline ripe & 34.88 & 0.65 & 35.53 & 27.04 \\
\hline Dieg bou gatt & 34.63 & 0.00 & 34.63 & 7.16 \\
\hline aborted & 56.50 & 0.00 & 56.50 & 1.35 \\
\hline ripe & 27.33 & 0.00 & 27.33 & 5.81 \\
\hline Valencia & 20.06 & 12.59 & 32.65 & 14.24 \\
\hline aborted & 27.50 & 18.40 & 45.90 & 7.11 \\
\hline ripe & 9.43 & 4.29 & 13.71 & 7.14 \\
\hline Boucodiékhal & 24.69 & 3.15 & 27.83 & 69.17 \\
\hline aborted & 26.50 & 4.62 & 31.12 & 41.73 \\
\hline immature & 0.00 & 0.00 & 0.00 & 2.44 \\
\hline ripe & 25.69 & 0.81 & 26.50 & 21.33 \\
\hline senescent & 10.50 & 0.00 & 10.50 & 3.67 \\
\hline Pêche & 23.30 & 2.80 & 26.10 & 7.08 \\
\hline aborted & 7.33 & 1.00 & 8.33 & 1.98 \\
\hline ripe & 30.14 & 3.57 & 33.71 & 5.10 \\
\hline Sanguine & 23.60 & 1.40 & 25.00 & 3.78 \\
\hline aborted & 3.00 & 0.00 & 3.00 & 0.65 \\
\hline ripe & 28.75 & 1.75 & 30.50 & 3.13 \\
\hline Colombo & 19.23 & 3.69 & 22.92 & 13.15 \\
\hline aborted & 20.75 & 5.13 & 25.88 & 5.47 \\
\hline ripe & 16.80 & 1.40 & 18.20 & 7.69 \\
\hline Haden & 6.85 & 13.92 & 20.77 & 15.32 \\
\hline aborted & 0.00 & 23.67 & 23.67 & 1.44 \\
\hline ripe & 8.90 & 11.00 & 19.90 & 13.88 \\
\hline Palmer & 13.75 & 5.00 & 18.75 & 4.41 \\
\hline aborted & 17.50 & 0.00 & 17.50 & 2.37 \\
\hline ripe & 15.20 & 0.00 & 15.20 & 8.14 \\
\hline
\end{tabular}


Table V. (continued)

Impact of the stage of development of the fruit on the Tephritidae emergence in mango varieties in orchards of the Niayes and Thiès Plateau zones, in Senegal.

\begin{tabular}{|c|c|c|c|c|}
\hline \multirow{2}{*}{$\begin{array}{l}\text { Varieties } \\
\text { and condition of fruit }\end{array}$} & \multicolumn{3}{|c|}{ Number of flies per kg fruits } & \multirow{2}{*}{$\begin{array}{l}\text { Quantity of fruits } \\
\text { (kg) }\end{array}$} \\
\hline & Bactrocera invadens & Ceratitis cosyra & Total flies & \\
\hline Sensation & 9.00 & 4.00 & 13.00 & 5.66 \\
\hline aborted & 5.67 & 0.00 & 5.67 & 2.00 \\
\hline ripe & 12.33 & 8.00 & 20.33 & 3.66 \\
\hline Birane Diop & 1.00 & 11.33 & 12.33 & 1.23 \\
\hline aborted & 0.00 & 0.00 & 0.00 & 0.20 \\
\hline ripe & 1.50 & 17.00 & 18.50 & 1.04 \\
\hline Amélie & 7.38 & 1.29 & 8.67 & 27.84 \\
\hline aborted & 9.11 & 2.44 & 11.56 & 6.41 \\
\hline ripe & 6.08 & 0.42 & 6.50 & 21.44 \\
\hline Early gold & 2.30 & 4.20 & 6.50 & 7.65 \\
\hline aborted & 0.33 & 1.67 & 2.00 & 2.93 \\
\hline ripe & 5.25 & 8.00 & 13.25 & 4.72 \\
\hline Koy khar & 6.00 & 0.00 & 6.00 & 2.06 \\
\hline aborted & 2.50 & 0.00 & 2.50 & 0.41 \\
\hline ripe & 9.50 & 0.00 & 9.50 & 1.65 \\
\hline Heidy & 3.67 & 0.00 & 3.67 & 6.55 \\
\hline ripe & 3.67 & 0.00 & 3.67 & 6.55 \\
\hline Divine & 0.33 & 3.00 & 3.33 & 5.30 \\
\hline aborted & 0.50 & 0.00 & 0.50 & 2.04 \\
\hline ripe & 0.25 & 4.50 & 4.75 & 3.26 \\
\hline Allongée & 3.00 & 0.00 & 3.00 & 2.32 \\
\hline aborted & 3.00 & 0.00 & 3.00 & 2.32 \\
\hline Irwin & 0.00 & 2.50 & 2.50 & 4.99 \\
\hline aborted & 0.00 & 7.00 & 7.00 & 1.47 \\
\hline ripe & 0.00 & 0.25 & 0.25 & 3.52 \\
\hline Ruby & 0.00 & 0.00 & 0.00 & 2.20 \\
\hline aborted & 0.00 & 0.00 & 0.00 & 0.72 \\
\hline ripe & 0.00 & 0.00 & 0.00 & 1.48 \\
\hline Zill & 0.00 & 0.00 & 0.00 & 0.70 \\
\hline aborted & 0.00 & 0.00 & 0.00 & 0.70 \\
\hline
\end{tabular}

aborted mangoes. The varieties Birane Diop, Valencia and Haden are significantly more infested by C. cosyra $(P<0.034)$, while $B$. invadens demonstrates no differences in infestation among varieties.

Mango infestations linked to C. cosyra, unlike $B$. invadens, showed significant differences based on skin color. Cerati- tis cosyra infested more greenish-yellow mangoes and yellow and green (aborted) mangoes than it did those that were red, reddish-yellow or reddish-green $(P<0.032)$. The extent of C.cosyra emergence increased as a function of fruit dimension but no significant differences were found between the different size classifications: 
0-5 cm, 5-10 cm, 10-15 cm and $15-20 \mathrm{~cm}$. Furthermore, infestations caused by B. invadens were greater on smaller mangoes $(0-5 \mathrm{~cm})$ than for the largest fruits $(P<0.039)$. While the average emergence values for $C$. cosyra were greater for fruits collected from the ground, those for B. invadens came from tree-harvested fruits. Notwithstanding these observations, there are no significant differences in emergence of these two species, irrespective of whether the fruits are sampled from the tree or from the ground $(P>0.05)$. Over the two seasonal flowering periods noted for the mango trees, the emergence of $B$. invadens was greater for the mangoes developing from the second flowering period $(P<0.017)$ unlike C. cosyra, for which emergence was more associated with the earlier flowering.

\section{Discussion}

The cultivated and self-seeded fruit plants found in the orchards were characterized by overlapping production periods. Therefore fruits, most of which are hosts for Tephritidae, were present at all times throughout the study. Tephritidae populations peaked during the fructification periods of certain selfseeded plants, mangoes and citrus. The naturally occurring fruit trees in and around the orchards play an important role in the Tephritidae population dynamic and in their species diversity. Moreover, there is an important role played in influencing species infestation and species strength by spiny woody perennials such as Ziziphus mauritiana and Capparis tomentosa used in the protective hedges for traditional orchards, both of them reaching maturation before mangoes. The jujube hosted Bactrocera invadens and Carpomyia sp., while the caper provided a refuge for Capparimyia bipustulata, Ceraritis capitata, C. cosyra and Bactrocera invadens. The climber Kedrostis hirtella, which grew on the other plants, hosted Bactrocera invadens as well as Dacus ciliatus, D. vertebratus and B. cucurbitae. These hosts were active outside the period for mangoes and the use of these prickly plants in the hedges of traditional orchards needs to be reconsidered in terms of managing B. invadens populations.

Meanwhile, research on parasitoids for biological control should focus on certain plants such as the caper because of their widespread presence. The importance of these alternative hosts in the traditional orchards means they were more infested than modern orchards. In effect, the traditional orchards were characterized by the diversity of fruit species and the complex of both local and improved varieties, whether late or early, that resulted from limited tending of stands and limited pesticide use. The resulting succession of flowering periods for the different fruit trees and plant hosts prolonged availability of both food and oviposition sites and helped maintain high population levels. Furthermore, the lack of pruning at the end of the season and the irregularity of collecting the highly susceptible aborted mangoes turned the traditional orchards into favorable havens of development for Tephritidae. A number of early and maincrop mangoes reached maturity in June and July. These included the varieties Séwé, Koy khar, Birane Diop, Greffal, Dieg bou gatt, David, Valencia, Colombo, Haden, Pêche, Amélie, Sensation, Early Gold, Irwin, Zill and Ruby. The late varieties took over from the end of July (David Haden, Palmer, Boucodiékhal, Divine, Heidy, Kent and Keitt). Therefore, these orchards reached high levels of emergence much earlier than in the so-called modern orchards. At the end of the mango season, these heavy populations of Tephritidae dropped quickly because of a scarcity of food and laying sites.

The game plan for $B$. invadens is characterized by rapid population increase and massive colonization of new habitat, followed by a rapid decline in numbers when conditions turn against it [7]. Among all the flies recorded here $B$. invadens had the largest range, corroborating reports from Mwatawala et al. [7] and Drew et al. [15]. Its laying capacity (794.6 eggs), its high net fertility (608.1 eggs), average deposition of 18.2 eggs per day, its ability to produce several broods each year and short breeding time [8] contributed to its abundance. Its polyphagous nature was proven by its 
infestation of 34 species of fruit tree in the Niayes and Thiès Plateau areas. Ceratitis cosyra behaved in the same way, but, on the other hand, C. bremii, C. punctata and Capparimyia bipustulata were more oligophagous and were retrieved from single fruit tree species: Cordyla pinnata, Achras sapota and Capparis tomentosa, respectively. In Cameroon, B. invadens was found in guava [16]. Among citrus trees, Fortunella japonica and $F$. margarita (limequat) were significantly more infested by $B$. invadens $(P<0.0001)$. The hybrid Fortunella $\times$ Citrus aurantifolia harbored 86 specimens per kg but was not significantly different to other species of Citrus. One explanation for the extent of the infestations on Fortunella might be its thinner skin than the other citrus cultivars studied.

The low infestation levels of $B$. invadens on certain citrus trees confirmed work carried out by Mwatawala et al. [17] in Tanzania and by Vayssières et al. [18] in Benin; yet B. invadens is predominant over C.capitata and $C$. cosyra on citrus trees. Other than mango, C. cosyra attacked cultivated fruits (Annona senegalensis, Citrus aurantium, Persea americana, Psidium guajava, [5, 1921], Citrus reticulata, C. sinensis and Butyrospermum parkii), and wild fruits (Sarcocephalus latifolius and Landolphia senegalensis) [22]. Before the arrival of Bactrocera invadens, Ceratitis cosyra predominated on C.quinaria (Bezzi) and C. silvestrii Bezzi, early species in Mali's mango season [23, 24]. Among the range of varieties found in the study zone, Ceratitis cosyra was the second most significant Tephritidae pest after B. invadens. However, large numbers of $C$. cosyra - up to 50 larvae per fruit [24] - emerged from Cordyla pinnata berries in this study, dominating those of B. invadens. In capers and sapodilla plums, Bactrocera invadens was dominated by, respectively, Capparimyia bipustulata and Ceratitis punctata. However, Carpomyia sp. attacking cultivated [25] and wild [26] jujube plants competed with $B$. invadens, which developed greater numbers of larvae in Gola jujube trees. Ceratitis capitata is a major pest of Solanaceae [27] but also damages citrus trees [28], guava and other wild and cultivated fruit trees [5, 20, 22].

Parameters such as fruit condition, color, size, flowering period, point of collection and variety had a strong influence on $B$. invadens and C. cosyra emergence in mangoes. There were no varietal differences evident in B. invadens infestations but $C$. cosyra was very significant in early varieties, particularly for green aborted mangoes and yellow ripe mangoes. Ceratitis cosyra is a major pest in fruits set in the first flowering period, which confirms its earliness in relation to the mango season $[22,28]$. On the other hand, Bactrocera invadens, which accounts for $58 \%$ of the total flies from yellow mangoes, was found on the full gamut of mango colors without significant difference in numbers. Females of Ceratitis species are attracted to the fruits by smell and color, particularly yellow, orange and red [28]. The Tephritidae emerged more frequently from mangoes retrieved from the ground than from those picked from trees. It seemed some Tephritidae preferred to lay eggs on shaded parts of fruits rather than on sunny surfaces [29].

This observation reinforced the importance of targeted control measures for fruit flies in orchards [30]. In Keitt, mangoes with cracks were significantly more infested by B. invadens because certain species of Bactrocera lay in the recent oviposition holes of other females or in fruit wounds [31]. The results showed that $B$. invadens infested even small fruits [28], but the greater the size of the fruit, the greater the emergence of C. cosyra. Moreover, shape and color became an olfactory stimulus for visiting fruits, making a hole and ovipositing [32]. Bactrocera invadens was more significant than Ceratitis cosyra in brown (chestnut) senescing fruits fallen to the ground. Certain Tephritidae maintain a symbiotic nutritional relationship with bacteria that supply them with amino acids and other growth factors in return for help with protection and dispersion of the bacteria [33]. The data on varietal influence of mango condition, color, size and collecting point on the emergence of B. invadens and C. cosyra revealed oviposition preferences. It seems that B. invadens was an invasive, polyphagous 
and colonizing species which competed with autochthonous Tephritidae. However, the dynamics of the two species do not clearly show the exclusion processes [7]. While B. invadens showed itself to be opportunistic and invasive, Ceratitis cosyra quickly peaked in conjunction with the seasonal stage of the mango, making C. cosyra a major pest in early cultivars [34].

\section{Conclusion}

The present study showed that the dynamics of the emergence of Tephritidae in orchards increased following the ripening periods of the main host plants (capers, mangoes, citrus and cucurbitaceous plants). Bactrocera invadens infests a number of fruit tree species in the Niayes and Thiès Plateau zones, including 13 citrus species, 24 varieties of mango and 18 other fruit species. These species are members of the Annonaceae, Apocynaceae, Capparidaceae, Caricaceae, Ceasalpiniaceae, Cucurbitaceae, Myrtaceae, Palmaceae Rhamnaceae, Rutaceae and Sapotaceae families. The diversity of fruit trees (cultivated and self-seeded), the lack of pest control and weak orchard care help sustain the Tephritidae outside the mango season. Once mango development gets underway, Bactrocera invadens and Ceratitis cosyra establish themselves in fruits dropped before maturation. The extent of their emergence varies from one orchard to another depending on the type of orchard, the species and varietal composition. The traditional type of orchard is more infested than the modern type. The physiological state of the fruit plays a far from negligible role in Tephritidae infestations. This fruit parameter must be taken into account in all comparative trials (variety comparisons, agronomic trials and inter-site comparisons).

\section{Acknowledgements}

We thank all the mango producers in the 19 orchards in Niayes and the Thiès Plateau for their collaboration and the Ecole Natio- nale Supérieure d'Agriculture, the National Parks Directorate, ED-SEV, CIRAD, USAID/ IPM CRSP, and the Director General of ISRA, Dr Macoumba Diouf, for grant support.

\section{References}

[1] Touré Fall S., Fall A.S., Cités horticoles en sursis ? L'agriculture urbaine dans les grandes Niayes au Sénégal, CRDI, Ottawa, Canada, 2001, 120 p.

[2] Rey J.-Y., Dia M.L., Mangues : des vergers villageois aux nouvelles plantations d'exportation, in: Duteurtre G., Faye M.D., Dieye P.N. (Eds.), L'agriculture sénégalaise à l'épreuve du marché, ISRA-Karthala, Dakar, Sénégal, 2010, 257-279.

[3] Ternoy J., Poublanc C., Diop M., Nugawela P., La chaîne de valeurs mangue au Sénégal: analyse et cadre stratégique d'initiatives pour la croissance de la filière, Unité BDS du programme USAID Croissance économique, Dakar, Sénégal, Sept. 2006, 90 p.

[4] Vayssières J.-F., Vannière H., Guèye P.S., Barry O., Hanne A.M., Korié S., Niassy A., Ndiaye M., Delhove G., Preliminary inventory of fruit fly species (Diptera, Tephritidae) in mango orchards in the Niayes region, Senegal, in 2004, Fruits 66 (2011) 91-107.

[5] De Meyer M., Revision of the subgenus Ceratitis (Ceratalaspis) Hancock [Diptera, Tephritidae], Bull. Entomol. Res. 88 (1998) 257-290.

[6] Norrbom, A.L., Carroll L.E., Thompson F.C., White I.M., Freidberg A., Systematic database of names, in: Thompson F.C. (Ed.), Fruit Fly Expert Identification System and Systematic Information Database, Backhuys Publ., Leiden, Neth., 1999, 65-251.

[7] Mwatawala M.W., De Meyer M., Makundi R.H., Maerere A.P., Seasonality and host utilization of the invasive fruit fly, Bactrocera invadens (Dipt., Tephritidae) in central Tanzania, J. Appl. Entomol. 130 (9-10) (2006) 530-537.

[8] Ekesi S., Nderitu P.W., Rwomushana I., Field infestation, life history and demographic parameters of the fruit fly Bactrocera invadens (Diptera: Tephritidae) in Africa, Bull. Entomol. Res. 96 (8) (2006) 379-386.

[9] Vayssières J.-F., Goergen G., Lokossou O., Dossa P., Akponon C., A new Bactrocera species in Benin among mango fruit flies 
(Diptera Tephritidae) species, Fruits 60 (2005) 371-377.

[10] Goergen G., Vayssières J.-F., Gnanvossou D., Tindo M., Bactrocera invadens (Diptera: Tephritidae), a new invasive fruit fly pest for the afrotropical region: host plant range and distribution in West and Central Africa, Environ. Entomol. 40 (4) (2011) 844-854.

[11] Cissé I., Utilisation des pesticides dans le système de production horticole dans la zone des Niayes : les produits et leurs impacts sur la nappe phréatique, Thesis, Géogr., Fac. Lettres, UCAD, Dakar, Sénégal, 2000, 187 p.

[12] Cissél., Fall S.T., Akinbamijo O.O., Diop Y.M., Adediran S.A., L'utilisation des pesticides et leurs incidences sur la contamination des nappes phréatiques dans la zone des Niayes au Sénégal, in: Akimbamijo O.O., Fall S.T., Smith O.B., Advances in crop-livestock integration in West African cities, CRDI, Ottawa, Canada, 2002, 85-100.

[13] Ba A.T., Madsen J.E., Sambou B., Flore, végétation et biodiversité au Sahel, AAU Rep. 39, Bot. Inst., Univ. AARHUS, Aarhus Univ. Press, Denmark, 1998.

[14] Anon., CONSERE, Expérience sénégalaise en matière de lutte contre la désertification, Conf. Mond. Désertification, 1997, 70 p.

[15] Drew R.A.I., Tsuruta K., White I.M., A new species of pest fruit fly (Diptera: Tephritidae: Dacinae) from Sri Lanka and Africa, Afr. Entomol. 13 (2005) 149-154.

[16] Ndzana A.F.X., Woin N., Kouodiekong L., Quilici S., Vayssières J.-F., Inventaire des espèces de mouches des fruits sur goyave dans la région de Yaoundé au Cameroun, Fruits 63 (1) (2008) 19-26.

[17] Mwatawala M.W., De Meyer M., Makundi R.H., Maerere A.P., Host range and distribution of fruit-infesting pestiferous fruit flies (Diptera, Tephritidae) in selected areas of Central Tanzania, Bull. Entomol. Res. (2009) 1-13.

[18] Vayssières J.-F., Sinzogan A., Adandonon A., Korie S., Diversity of fruit fly (Diptera: Tephritidae) species associated with Citrus crops (Rutaceae) in southern Benin in 2008-2009, Int. J. Biol. Chem. Sci. 4 (2010) 1881-1897.

[19] Hancock D.L., Notes on some African Ceratitinae (Diptera: Tephritidae) with special reference to the Zimbabwean fauna, Trans. Zimb. Sci. Assoc. 63 (1987) 47-57.
[20] White I.M., Elson-Harris M., Fruit flies of significance: their identification and bionomics, Cab Int., Aciar, Redwood Press, Melksham, U.K., 1992, 601 p.

[21] De Meyer M., Copeland R.S., Lux S.A., Mansell M., Quilici S., Wharton R., White I.M., Zenz N., Annotated check list of host plants for afrotropical fruit flies (Diptera: Tephritidae) of the genus Ceratitis, Doc. Zool., Mus. R. Afr. Cent. 27 (2002) 1-91.

[22] Noussourou M., Diarra B., Lutte intégrée contre les mouches des fruits, Sahel IPM (1995) 2-13.

[23] Vayssières J.-F., Sanogo F., Noussourou M., Inventaire des espèces de mouches des fruits (Diptera : Tephritidae) inféodées au manguier au Mali et essais de lutte raisonnée, Fruits 59 (2004) 1-14.

[24] Malio E., Observations on the mango fruit fly Ceratitis cosyra in the Coast Province, Kenya, Kenya Entomol. Newsl. 19 (7) (1979).

[25] Awadallah A., Selim O.F., Fouda S., Hashem A.G., The chemical control of Ziziphus fruit fly, Carpomyia incomplete Becker in the Assiut area, Agric. Res. Rev. 53 (1975) 123125

[26] Hendel F., Trypetidae, in: Lindner E. (Ed.), Die Fliegen der Palaearktischen Region, Vol. 5, Lieferung 49, SchweizerbartÖschen Verlagsbuchhandlung, Stuttg., Ger., 1927, 221 p.

[27] Vayssières J.F., Carel Y., Les Dacini (Diptera : Tephritidae) inféodées aux Cucurbitaceae à la Réunion : gamme de plantes hôtes et stades phénologiques préférentiels des fruits au moment de la piqûre pour des espèces cultivées, Ann. Soc. Entomol. Fr. 35 (1999) 197-202.

[28] Vayssières J.-F., Korie S., Coulibaly O., Temple L., Boueyi S.P., The mango tree in central and northern Benin: cultivar inventory, yield assessment, infested stages and loss due to fruit flies (Diptera Tephritidae), Fruits 63 (2008) 335-348.

[29] Syed R.A., Studies on the ecology of some important species of fruit flies and their natural enemies in West Pakistan, CIBC, Commonw. Agric. Bureau, U.K., 1969, 12 p.

[30] Verghese A., Madhura H.S., Jayanthi P.D.K., Stonehouse J.M., Fruit flies of economic significance in India with special reference to Bactrocera dorsalis Hendel, in: Barnes B., Addison M. (Eds.), Proc. 6th Int. Symp. Fruit 
Flies of Economic Importance, May 2002, Stellenbosch, S. Afr., 2003, 6-10.

[31] Prokopy R.J., Koyama J., Oviposition site partitioning in Dacus cucurbitae, Entomol. Exp. Appl. 31 (1982) 428-432.

[32] Fletcher B.S., The biology of dacine fruit flies, Annu. Rev. Entomol. 32 (1987) 115-144.

[33] Drew R.A.I., Lloyd A., Bacteria associated with fruit flies and their host plants, in:
Robinson G., Hooper A.S. (Eds.), Fruit flies: their biology, natural enemies, and control, World crop pests, Elsevier, Amst., Neth., 1989, 129-140.

[34] Vayssières J.-F., Korie S., Ayegnon D., Correlation of fruit fly (Diptera Tephritidae) infestation of major mango cultivars in Borgou (Benin) with abiotic and biotic factors and assessment of damage, Crop Protect. 28 (2009) 477-488.

\section{Estacionalidad y gama de las moscas de las frutas (Tephritidae, dípteros) identificadas en las plantas huésped de los vergeles de Niayes y de la meseta de Thies (Senegal).}

Resumen - Introducción. La producción de fruta de Senegal se estima en 150.000 t, de las cuales 60.000 t son mangos. Los cítricos representan el $24 \%$ de esta producción y se sitúan en segunda posición, después del mango, el cual representa el 60\% de la producción frutera, la cual es muy importante en las Niayes. Con la llegada de Bactrocera invadens a Senegal aumentaron las pérdidas de producción de mangos. Las poblaciones de la plaga son considerables en periodos de maduración de los frutos, pero las informaciones referentes a sus huéspedes secundarios son escasas. Material y métodos. Se cosecharon de modo habitual los frutos de las especies fruteras cultivadas y espontáneas, de abril a diciembre de 2008, en 19 vergeles y en su alrededor, en once localidades de la zona de las Niayes y de la meseta de Thies (Senegal). Se hizo el seguimiento de estos frutos para determinar las especies de las moscas hospedadas, y hacer así un repertorio de sus plantas huésped. En el caso del mango, el estudio pretendió mostrar la influencia de parámetros, tales como: la variedad, el tamaño del fruto, el color, la ola de floración o el estado fisiológico en las infestaciones por B. invadens y Ceratitis cosyra. En función de su composición y de su modo de conducta, se clasificaron los vergeles en dos tipos: tradicional (numerosas variedades de mangos y numerosas especies de frutas cultivadas a la vez en el seno de una misma parcela) o moderno (parcelas monovarietales de mangos). Resultados y discusión. En total, se sacaron muestras tanto en el suelo como en el árbol de 663,2 kg de frutos, correspondientes a 24 variedades de mangos, 13 especies de cítricos, de las cuales 5 variedades de limero, 2 variedades de naranjos y 4 variedades de pomelos, así como otras especies fruteras cultivadas o espontáneas. Los vergeles de tipo tradicional se infestaron más que los vergeles de tipo moderno. Entre los Tephritidae pertenecientes a los frutos cosechados, la especie $B$. invadens fue significativamente dominante en Ceratitis cosyra, C. capitata, C. punctata, C. bremii, Bactrocera cucurbitae, Capparimyia bipustulata, Carpomyia sp. y Dacus sp. La especie B. invadens se encontró en 24 variedades de Mangifera indica, 19 cultivares de cítricos, y en otras especies fruteras cultivadas y espontáneas. Algunas plantas huésped mantuvieron los niveles de poblaciones de B. invadens antes del periodo de maduración del mango. El mango se infestó principalmente por $B$. invadens y $C$. cosyra. La especie $C$. cosyra es significativamente importante en los frutos correspondientes a las primeras olas de floración y, sobre todo, en las variedades precoces, mientras que $B$. invadens está presente en todas las variedades, independientemente del estado del fruto, su color, la ola de floración y el lugar de cosecha. Conclusión. Dada la diversidad de las plantas huésped y de las variedades, los vergeles tradicionales fueron más infestados que los vergeles modernos. El control de esta plaga precisa definir un sistema de lucha integrada basada en un estudio de base de las moscas de las frutas presentes, de los parasitoides existentes y de sus huéspedes.

Senegal / frutales / plantas huéspedes / Mangifera indica / Citrus / Tephritidae / Bactrocera invadens / Ceratitis cosyra / huerto frutal / muestra 